\title{
Kilka uwag o responsywności prawa podatkowego na przykładzie urzędowych interpretacji prawa podatkowego
}

\section{Wprowadzenie}

Wskazuje się, że jedną z funkcji prawa powinno być osiąganie ładu społecznego, a więc - przyjmując za S. Wronkowską - „pewnego stanu stosunków społecznych w grupie, powstającego w następstwie respektowania w tej grupie określonych norm postępowania, między innymi norm prawnych. System prawa może sprzyjać osiąganiu określonego ładu społecznego i współtworzyć go, w szczególności wtedy, gdy zawiera normy służące rozwiązywaniu spraw społecznych zgodnie z przyjętym w danej społeczności systemem wartości i gdy normy te charakteryzują się określonymi walorami prakseologicznymi"1.

Rewersem tej konstatacji jest spostrzeżenie, że zauważalne tendencje rozwoju stosunków społecznych powinny być zawsze uwzględniane w refleksji naukowej nad instytucjami prawnymi. Trafnie uzasadnił to Z. Ziembiński, podkreślając, że "należy też pamiętać, iż normy systemu prawnego są rezultatem nie tylko aktów wydawania przepisów, lecz także związane są w złożony sposób, z różnego rodzaju wytworzonymi przez doktrynę prawniczą «ogólnymi zasadami prawa» i z dyrektywami celowościowymi opartymi na dostrzeganych prawidłowościach zjawisk życia społecznego" ${ }^{\prime 2}$. Innymi więc słowy, naturalną konsekwencją

${ }^{1}$ S. Wronkowska, Z. Ziembiński, Zarys teorii prawa, Poznań 2001, s. 195.

2 Z. Ziembiński, "Lex" a "ius" w okresie przemian, "Państwo i Prawo” 1991, z. 6, s. 8. 
twierdzenia, że prawo ma organizować stosunki społeczne, jest spostrzeżenie, iż wnioski z analizy tych stosunków i zachodzących w nich zmian powinny wpływać na kształt przyjmowanych rozwiązań prawnych, a z drugiej strony, że analiza przeobrażeń systemu prawnego pozwala uchwycić tendencje rozwoju zarówno poszczególnych jego instytucji, jak i stosunków społecznych pomiędzy jego adresatami.

Nie budzi przy tym wątpliwości teza, że skuteczność obowiązujących instytucji prawnych zależy w dużej mierze od tego, czy na etapie ich projektowania uwzględniono $\mathrm{w}$ odpowiednim zakresie owe "dostrzegane prawidłowości zjawisk życia społecznego" i ustaloną tradycję kultury prawnej. Pominięcie tego rodzaju refleksji może na etapie stosowania prawa prowadzić do jego nieskuteczności w danym obszarze stosunków społecznych, a w efekcie do wysoce szkodliwego stanu stosowania prawa jedynie w imię dochowania formalnej praworządności, w ramach źle pojętego legalizmu ${ }^{3}$, a w konsekwencji nawet naruszać ład społeczny.

Wydaje się przy tym, że w obszarze dogmatyki prawa wskazane powyżej podejście nie jest szczególnie popularne. Tym bardziej interesująco jawią się opracowania uwzględniające zasygnalizowane potrzeby. W tym kontekście należy koniecznie przywołać opublikowane przed kilku laty opracowanie B. Brzezińskiego Urzędowe interpretacje prawa podatkowego. Kilka refleksji na tle ewolucji systemu prawnego ${ }^{4}$. Autor ten, wychodząc także z założenia, że warunkiem skuteczności prawa jest „podporządkowanie go ogólnym prawidłom ewolucji życia społecznego" ${ }^{\prime \prime}$, podjął próbę spojrzenia na regulację urzędowych interpretacji prawa podatkowego w odniesieniu do podstawowych założeń koncepcji rozwoju prawa P. Selznicka i P. Noneta ${ }^{6}$, przybliżonej polskiemu czytelnikowi głównie dzięki opracowaniom E. Kustry ${ }^{7}$ i M. Zirk-Sadowskiego ${ }^{8}$. Szczególnie interesującym wnioskiem B. Brzezińskiego jest konstatacja, że „instytucja urzędowych interpretacji odpowiada modelowi prawa

${ }^{3}$ Por. T. Rabska, Jakie prawo gospodarcze? Próba odpowiedzi, „Ruch Prawniczy, Ekonomiczny i Socjologiczny" 1993, z. 1, s. 19-25.

${ }^{4}$ B. Brzeziński, Urzędowe interpretacje prawa podatkowego. Kilka refleksji na tle ewolucji systemu prawa, „Kwartalnik Prawa Podatkowego” 2012, nr 1, s. 51-60.

${ }^{5}$ Ibidem, s. 51.

${ }^{6}$ Zob. P. Selznick, P. Nonet, Law and Society in Transition: Toward Responsive Law, New York 1978.

7 Zob. E. Kustra, Polityczne problemy tworzenia prawa, Torun 1994.

${ }^{8}$ M. Zirk-Sadowski, Transformacja prawa podatkowego a jego wykładnia, „Kwartalnik Prawa Podatkowego" 2004, nr 4, s. 9-20. 
responsywnego i jest wyrazem realizacji tego modelu" ${ }^{\prime \prime}$. Uprzedzając nieco dalsze rozważania na temat responsywności prawa, wypada już w tym miejscu wyjaśnić, iż przywołany pogląd należy rozumieć w ten sposób, że polska regulacja urzędowych interpretacji prawa podatkowego odpowiada modelowi, w którym "prawo nastawione jest w większym stopniu niż poprzednio na potrzeby społeczne, artykułowane przez reprezentację społeczeństwa, a mniej na «własne» potrzeby władzy. Charakteryzuje się ono rosnącą współpracą uczestników stosunków prawnych, miękkimi sposobami rozwiązywania konfliktów (mediacja, koncyliacja, arbitraż), elastycznością w stosowaniu prawa do konkretnych sytuacji"10.

Jak wskazano w tytule, rozważania podejmowane w ramach niniejszego artykułu również koncentrują się wokół regulacji urzędowych interpretacji prawa podatkowego. W związku z tym wypada wyjaśnić, że założeniem autorów jest kontynuacja i pogłębienie refleksji zainicjowanej przez B. Brzezińskiego. Cel ten znajduje przy tym uzasadnienie nie tylko $\mathrm{w}$ związku z zaaprobowaniem postulatów przybliżonych w pierwszych akapitach. Za przypomnieniem badań B. Brzezińskiego i ich kontynuacją przemawia także okoliczność, że w dniu 22 marca 2016 r. wpłynął do sejmu Rządowy projekt ustawy o zmianie ustawy Ordynacja podatkowa oraz niektórych innych ustaw ${ }^{11}$. Przewiduje on między innymi zmiany w przepisach dotyczacych indywidualnych interpretacji podatkowych. Na szczególną uwagę zasługuje rozwiązanie, wedle którego organ podatkowy nie będzie zobowiązany do ustosunkowywania się w treści interpretacji do tych elementów stanu faktycznego lub zdarzenia przyszłego, co do których istnieje uzasadnione przypuszczenie, że mogły/mogą być podjęte w związku z unikaniem opodatkowania lub stanowić nadużycie prawa. Oczywiście, ostateczny kształt projektowanej nowelizacji nie jest możliwy do przewidzenia, a proponowane zmiany zapewne będą jeszcze przedmiotem ożywionej dyskusji. Z całą jednak pewnością warto już teraz podjąć i włączyć $\mathrm{w}$ ramy owej dyskusji refleksję w perspektywie zaproponowanej przez B. Brzezińskiego. We wskazanym kontekście powstają bowiem niezwykle interesujące i praktycznie doniosłe pytania o ocenę projektowanego rozwiązania w świetle postawionej przez tego autora tezy. Nie wdając

\footnotetext{
${ }^{9}$ B. Brzeziński, Urzędowe interpretacje..., op. cit., s. 55.

${ }^{10}$ Ibidem, s. 52.

${ }^{11}$ Druk sejmowy nr 367.
} 
się w rozważania na temat legislacyjnej poprawności i słuszności proponowanych rozwiązań, warto się zastanowić, czy i jak przyjęte zmiany mogą wpłynąć na kształt relacji podatnik-administracja podatkowa.

\section{Pojęcie responsywności}

Punktem odniesienia dla podejmowanej analizy urzędowych interpretacji prawa podatkowego ma być postulat responsywności prawa, a zatem należy określić znaczenie tego pojęcia. Skoro zaś zostało ono zaczerpnięte do dyskusji nad tą instytucją z koncepcji P. Selznicka i P. Noneta, warto rozpocząć od jej przybliżenia. Autorze ci wyróżnili trzy etapy ewolucji systemów prawnych: represyjny, autonomiczny i responsywny. Jak wcześniej wspomniano, ich charakterystyka została już przedstawiona w polskiej literaturze. Niemniej dla zapewnienia przejrzystości niniejszego opracowania zasadne wydaje się jej skrótowe przywołanie i odniesienie do tendencji rozwoju polskiego prawa podatkowego. Najpełniejszą do tej pory analizę tej koncepcji przeprowadziła E. Kustra. Wskazuje ona, że dla modelu prawa represyjnego charakterystyczne są następujące cechy:

„a) celem prawa jest legitymizacja porządku politycznego, prawo jest podporządkowane polityce;

b) przymus jest ekstensywny i słabo ograniczony;

c) dominuje «oficjalna» moralność;

d) reguły prawne są surowe i szczegółowe, słabo wiążą rządzących;

e) uzasadnienie decyzji prawnych (tworzących prawo, stosujących prawo) oparte jest na racjach politycznych korzystnych dla rządzących i nierzadko charakteryzuje się odwołaniem do interesów partykularnych.

Typ prawa autonomicznego związany jest z następującymi atrybutami:

a) celem prawa jest legitymizacja władzy, prawo jest autonomiczne względem polityki;

b) przymus jest kontrolowany i ograniczony prawem;

c) przestaje dominować «oficjalna» moralność;

d) reguły prawne są generalne, $\mathrm{w}$ równym stopniu wiążą rządzących, jak i rządzonych;

e) uzasadnienie decyzji prawnych (tworzących prawo, stosujących prawo) preferuje formalną zgodność z prawem;

f) istnieje «test legalności» aktów tworzenia i stosowania prawa"12.

${ }^{12}$ E. Kustra, op. cit., s. 35. 
Zestawiając przywołaną charakterystykę z wiedzą na temat przeobrażeń, jakie dokonywały się $\mathrm{w}$ polskim systemie prawnym od końca lat osiemdziesiątych XX w., dochodzi się do wniosku, że co do zasady odpowiadaja one ewolucji od systemu prawa represyjnego do autonomicznego w ujęciu P. Noneta i P. Selznicka. Oczywiście, trzeba podkreślić, że zmiany w żadnym razie nie dokonują się od razu, obejmując wszelkie urządzenia danego systemu. B. Brzeziński stwierdza, że przywołany tu model "nie ma (i chyba nie może mieć) precyzyjnej chronologii. Wskazane etapy rozwoju prawa nie dadzą się zamknąć w ścisłych ramach czasowych, a odzwierciedlają jedynie ogólny kierunek rozwoju prawa"13. Jakkolwiek koncepcja określa tylko pewne modele wyidealizowane, to jednak na podstawie charakteryzujących je elementów można wskazać właściwe im odpowiedniki rzeczywiste na podstawie analizy historycznej. Kierunek zmian polskiego systemu jest szczególnie widoczny na obszarze szeroko pojętego prawa publicznego. To oczywiste, jeśli wziąć pod uwagę fakt, że zaproponowane przez P. Noneta i P. Selznicka elementy różnicujące poszczególne etapy rozwojowe określają $\mathrm{w}$ istocie charakter relacji pomiędzy władzą państwową a obywatelami. $Z$ tego względu tak rozumianą ewolucję możemy, niczym w probówce, obserwować w procesie transformacji polskiego prawa podatkowego ${ }^{14}$.

Represyjność modelu systemu prawnego PRL w zakresie prawa podatkowego nie budzi wątpliwości. Można bowiem stwierdzić, że regres, jaki nastąpił w polskim prawie podatkowym w okresie PRL, wyrażał się przede wszystkim w likwidacji mechanizmów ograniczających dominującą pozycję władzy względem podatnika ${ }^{15}$. Innymi słowy, polegał na wyrugowaniu z systemu podatkowego instytucji o charakterze gwarancyjnym, tak niezbędnych przecież w przypadku stosunków prawnych,

\footnotetext{
${ }^{13}$ B. Brzeziński, Urzędowe interpretacje..., op. cit., s. 51 i n.

${ }^{14} \mathrm{Na}$ ten temat zob. szerzej: B. Brzeziński, Zmiany w układzie stosunków pomiędzy podatnikami a organami podatkowymi jako cel reformy systemu podatkowego (poszukiwanie rozwiązań instytucjonalnych), "Acta Universitatis Nicolai Copernici, Prawo” XXXIV, Toruń 1994; M. Zirk-Sadowski, op. cit.; C. Kosikowski, Podatki. Problem władzy publicznej i podatników, Warszawa 2007; J. Małecki, Ewolucja systemu i prawa podatkowego w Polsce, w: Nauka finansów publicznych i prawa finansowego w Polsce. Dorobek i kierunki rozwoju. Ksiega jubileuszowa profesor Alicji Pomorskiej, pod red. J. Głuchowskiego, C. Kosikowskiego, J. Szołno-Koguc, Lublin 2008, s. 303-313; W. Morawski, Interpretacje prawa podatkowego i celnego - stabilność i zmiana, Warszawa 2012.

${ }^{15}$ Poza wszystkim innym działania władz w tamtym okresie stanowiły podważenie fundamentów polskiej kultury prawnej - wszak rozwój mechanizmów gwarancyjnych w Polsce był najpoważniejszym bodaj wkładem polskiego prawodawstwa do dorobku światowej myśli podatkowej; por. J. Małecki, op. cit., s. 303 i n.
} 
których charakterystyczną cechą jest nierównorzędność podmiotów. By twierdzenie to poprzeć przykładem, można wskazać całkowite zignorowanie tradycji, zgodnie z którą tylko parlament władny jest regulować system podatkowy. Właściwe dla PRL tzw. „powielaczowe prawo podatkowe" skutecznie uniemożliwiało realizację fundamentalnego postulatu wobec prawa - jego pewności.

Wyraźnie widoczne było też przejście od modelu prawa represyjnego do autonomicznego. Jak wiadomo, społeczne konsekwencje coraz gwałtowniej ujawniającej się niewydolności systemu prawnego, a za nim ustroju gospodarczego PRL, zaowocowały wprowadzeniem do systemu nowych urządzeń prawnych ograniczających represyjność prawa. Pierwsze istotne zmiany nastąiły już w połowie lat osiemdziesiątych XX w. - wprowadzono wówczas m.in. sądową kontrolę administracji, utworzono Trybunał Konstytucyjny, instytucję Rzecznika Praw Obywatelskich, a bezpośrednio na gruncie prawa podatkowego przywrócono zasadę nullum tributum sine lege ${ }^{16}$. Oczywiście, ewolucja prawa jest procesem płynnym, w którym nowe rozwiązania nie usuwają wcześniejszych bez reszty. Toteż również po roku 1989 - a być może także obecnie dostrzeżemy w systemie prawnym elementy, które zgodnie z przyjętą klasyfikacją określilibyśmy jako represyjne ${ }^{17}$. Jednakże ze względu na przyjęte tu główne kryterium rozróżnienia - relację pomiędzy władzą a obywatelem - można z pewnością powiedzieć, że istotą transformacji systemu prawnego, w szczególności zaś prawa podatkowego, było wyraźne przejście od modelu represyjnego do autonomicznego, gdzie „prawo przestaje być rodzajem instrukcji przekazywanej przez suwerena, stając się wyemancypowanym w stosunku do systemu politycznego mechanizmem racjonalizacji celów społecznych i ideałów"18.

Zjawisko to zarysowało się wyraźnie zarówno w treści tworzonego prawa, jak i w praktyce jego stosowania, a przywołana - jako nadrzędna idea polskiej transformacji - zasada państwa prawnego stała się determinantą wszelkich działań $w$ ramach ustroju ${ }^{19}$. Z interesującego nas punktu widzenia istotne jest to, że charakterystyczną cechą auto-

${ }^{16}$ Por. Ustawa z dnia 19 XII 1980 r. o zobowiązaniach podatkowych (Dz.U. Nr 27, poz. 111 ze zm.).

${ }^{17}$ Szerzej B. Brzeziński, Urzędowe interpretacje..., s. 53 i n.

${ }^{18}$ M. Zirk-Sadowski, op. cit., s. 11.

${ }^{19}$ Por. M. Kordela, Rola zasady państwa prawnego w budowie aksjologii prawa. Uwagi na tle orzecznictwa Trybunału Konstytucyjnego, w: Zmiany społeczne a zmiany w prawie. Aksjologia, konstytucja, integracja europejska, pod red. L. Leszczyńskiego, Lublin 1999, s. 175-180. 
nomicznego modelu prawa jest jego gwarancyjny charakter. Wynika to z faktu, iż ewolucja dokonuje się jako konsekwencja sprzeciwu wobec założeń modelu represyjnego i jako taka dąży w pierwszej kolejności do umocnienia wypracowanych mechanizmów gwarancyjnych, a naczelne dyrektywy funkcjonowania aparatu państwowego w systemie prawa autonomicznego to postulat pewności prawa i zasada budowania zaufania do państwa.

Dopiero po dokonaniu powyższych ustaleń podjąć można interpretację pojęcia responsywności. Ostatni etap w modelu P. Noneta i P. Selznicka charakteryzują następujące atrybuty:

„a) celem prawa jest adaptacyjne i zróżnicowane oddziaływanie na rzeczywistość społeczną - prawo jest «otwarte» na potrzeby i dążenia społeczne;

b) przymus jest zastąpiony samoograniczającymi się zobowiązaniami;

c) moralność ma charakter obywatelski, zakłada kooperację w społeczeństwie;

d) reguły prawne są «otwarte», często mają charakter klauzul generalnych i są podporządkowane zasadom prawa;

e) uzasadnienie decyzji prawnych (tworzących prawo, stosujących prawo) ma charakter celowościowy" ${ }^{\prime 20}$.

Łatwo zauważyć, że o ile w przypadku represyjnego i autonomicznego modelu prawa przyswojenie podstawowych założeń i zarazem wskazanie konkretnych rozwiązań jako przykładowych "desygnatów" nie jest szczególnie skomplikowane, o tyle już próba precyzyjnego określenia rozwiązań, które bez zastrzeżeń charakteryzowalibyśmy jako responsywne, powoduje trudności. Podobnie skomplikowanym zadaniem jest wytyczenie granicy pomiędzy drugim i trzecim etapem w tak ujętym modelu rozwoju prawa. Podkreśla to również E. Kustra, stwierdzając, że "przejście od prawa autonomicznego do prawa responsywnego jest mniej wyraźne. Nie jest ono «przełomem» w rozwoju prawa, za który można uznać przejście od prawa represyjnego do prawa autonomicznego. Podwaliny "prawa responsywnego» buduje prawo autonomiczne, ono bowiem stwarza zaplecze dla prawa responsywnego, jako przedmiotu społecznej aktywności, a także jako środka realizacji celów działających podmiotów społecznych"21. Trudność wynika więc $z$ tej okoliczności, że system prawa responsywnego nie powstaje

\footnotetext{
${ }^{20}$ E. Kustra, op. cit., s. 35 .

${ }^{21}$ Ibidem, s. 37.
} 
w kontrze do etapu go poprzedzającego, lecz jest jego konsekwencją. Fakt, iż model responsywny wyrasta $\mathrm{z}$ autonomicznego, sprawia, że elementy charakterystyczne dla obu etapów w istocie koegzystują w ramach systemów prawnych, a nawet poszczególnych jego instytucji.

Dla pełnego scharakteryzowania pojęcia responsywności należy odwołać się do kontekstu naukowego dyskursu, w jakim zostało ono wypracowane. W filozofii prawa II połowy XX w. wyraźnie zarysował się nurt rozważań dotyczących prawa w ujęciu argumentacyjno-dyskursywnym. Poglądy wpisujące się w ów nurt stanowiły krytyczną odpowiedź na koncepcję pozytywizmu prawniczego, a opierały się głównie na konstatacji, że pozytywistyczny model nie oferuje instrumentów umożliwiających skuteczne rozwiązywanie konfliktów społecznych. Wskazywano, że wobec zachodzących w społeczeństwach zmian istnieje potrzeba wypracowania nowych modeli ich funkcjonowania. Podstawowym założeniem stało się przekonanie, że prawo nie jest skuteczne, gdy ogranicza się jedynie do swej funkcji deontologicznej. Popularność zyskiwał pogląd, że relacja między władzą a obywatelami powinna być oparta na zasadzie partycypacji tych drugich w procesie sprawowania władzy, a efektem współpracy powinien być konsensus ${ }^{22}$. Gdy idzie o pojęcie responsywności, koniecznie trzeba zaznaczyć, że do filozoficznego dyskursu wprowadził je R.A. Dahl. Wskazuje się ${ }^{23}$, że pojęcie responsywności stało się przedmiotem szerszej naukowej dyskusji w związku z rozwojem koncepcji dotyczącej tzw. demokracji partycypacyjnej w końcu lat sześćdziesiątych ubiegłego wieku, a rolę szczególną odegrała tu Dahlowska Polyarchy: Participation and Opposition (1971). Poczynając od Dahla, poprzez koncepcje komunikacyjne,

${ }^{22} \mathrm{Na}$ marginesie warto odnotować, że podobne intuicje co do tendencji rozwoju systemów prawnych prezentowane były także na obszarze polskiego prawoznawstwa. Na szczególną uwagę zasługuje ukończona już w 1945 r. rozprawa M. Zimmermanna Pojęcie administracji publicznej a "swobodne uznanie", w której autor przewidywał, iż „należy raczej sądzić, że wraz z konsolidowaniem się społeczeństw i postępującą ich socjalizacją będzie się zwiększać wpływ obywateli na życie prawne. [...]. Rozbudowanie zaś demokracji w kierunku zwiększenia wpływu obywateli zarówno na samo tworzenie norm prawnych, jak i współudziału jednostki w tworzeniu dotyczących jej aktów administracyjnych, szerokiej kontroli społeczeństwa i wzrostu solidarności społecznej uczynią z przymusu państwowego gwarancję rzeczywiście tylko ostateczną". Przywołana teza M. Zimmermanna w pełni odpowiada właśnie modelowi prawa responsywnego. Zob. M. Zimmermann, Pojeccie administracji publicznej a "swobodne uznanie", Warszawa 2010.

${ }^{23}$ Zob. J. Herbst, O kategorii "responsywności" władzy i o pewnym warunku responsywności władzy w Polsce, "Zarządzanie Publiczne” 2008, nr 4, s. 94. 
w szczególności C. Perelmana, J. Habermasa, a dalej także P. Noneta i P. Selznicka, responsywność powiązana została z koniecznością prowadzenia uczciwego, równego, uwzględniającego preferencje uczestników dyskursu w relacji pomiędzy władzą a obywatelami. Można by rzec, iż responsywność systemu prawnego oznacza jego rzeczywista, a nie tylko formalną zdolność do reagowania na potrzeby społeczne w warunkach - by odwołać się do J. Habermasa - „idealnej sytuacji mowy"24. Innymi słowy, funkcją prawa powinien być ład społeczny, co jednak szczególnie istotne - nie tylko oparty na instytucjach o charakterze gwarancyjnym, lecz za ich pomocą zapewniający elastyczne procedury interakcji pomiędzy podmiotami stosunków społecznych. Należy też odnotować, że z czasem postulat responsywności został przyjęty na gruncie teorii zarządzania oraz nauki administracji, a następnie trafił do dokumentów i soft law organizacji międzynarodowych ${ }^{25}$ oraz instytucji Unii Europejskiej ${ }^{26}$, stając się - jak się obecnie wydaje - nowym paradygmatem zarządzania publicznego, w szczególności w ramach nurtu governance ${ }^{27}$.

Przywołanie tej okoliczności jest o tyle przydatne, że pozwala dopełnić rozumienie pojęcia responsywności poprzez wzbogacenie rozważań o perspektywę, jaką powinny ${ }^{28}$ przyjmować polskie organy administracji publicznej, a więc także organy administracji podatkowej. Governance określa się jako „bardziej «miękką» formułę zarządzania publicznego jako procesu opartego na niewymuszonym współdziałaniu samodzielnych podmiotów współpracujących na zasadzie zaufania

${ }^{24}$ Idealna sytuacja mowy to - jak trafnie charakteryzuje J. Stelmach - „taka sytuacja, w której komunikacja nie jest zakłócona ani przez przymus zewnętrzny, ani wewnętrzny, mający swe źródło w samej strukturze argumentacji. Proces komunikacji wtedy tylko nie wytwarza przymusu, gdy uczestnikom dyskursu dany jest symetryczny przydział szans wyboru i dokonywania aktów mowy. Dlatego przyjmujemy na przykład tylko takie normy, które «mogą mieć wszyscy», czy też takie, których konsekwencje i skutki uboczne mogą być przez wszystkich zaakceptowane. Ten formalnie rozumiany dyskurs prowadzony jest w ramach "wspólnoty komunikacyjnej», a uzyskany tam konsens legitymowany jest ostatecznie «siłą lepszego argumentu»", J. Stelmach, R. Sarkowicz, Filozofia prawa XIX i XX wieku, Kraków 1999, s. 167.

${ }^{25}$ Zob. np. D.A. Rondinelli, Governments Serving People: The Changing Roles of Public Administration in Democratic Governance, w: Public Administration and Democratic Governance: Governments Serving Citizens, ed. by D.A. Rondinelli, ONZ 2006, s. 7-8.

${ }^{26}$ Zob. np. Komisja Europejska, Zarzadzanie Europa - Biała Księga Komisji Europejskiej, Bruksela 2001.

${ }^{27} \mathrm{Na}$ ten temat zob. M. Stępień, Responsywna administracja publiczna, Toruń 2008.

${ }^{28}$ Zob. Ministerstwo Rozwoju Regionalnego, Departament Koordynacji Polityki Strukturalnej, Koncepcja Good Governance - Refleksje do dyskusji, Warszawa 2008. 
i współodpowiedzialności"29. Podobnie w literaturze europejskiej wskazuje się, że "koncepcja zarządzania odwołuje się do stworzenia struktury bądź porządku, który nie może zostać wymuszony z zewnątrz, ale pojawia się jako wynik interakcji pomiędzy różnorodnymi, wpływającymi na siebie wzajemnie aktorami"30.

Mając już podstawową wiedzę na temat koncepcji, w ramach których wypracowano pojęcie responsywności, wypada określić jego treść. Dobrym - bo odnoszącym się zarówno do filozofii prawa, jak i teorii zarządzania - podsumowaniem może być konstatacja J. Herbsta: „na płaszczyźnie aksjonormatywnej responsywność rodzi się wraz z zaakceptowaniem przez elitę rządzącą (ale też rządzonych) założenia o potrzebie permanentnej interakcji pomiędzy systemem administracji publicznej a przedmiotem i podmiotami jego oddziaływania. Na płaszczyźnie strukturalnej kluczowym warunkiem jest «włączenie» tej interakcji do arsenału procedur regulujących funkcjonowanie administracji publicznej. Na płaszczyźnie behawioralnej istotne znaczenie ma skuteczne stosowanie tych procedur (nie tylko na poziomie «komunikacji» $\mathrm{z}$ odbiorcami polityki albo diagnozowania potrzeb, lecz także na poziomie reakcji na postulaty będące efektem tej komunikacji), a na płaszczyźnie funkcjonalnej - ich «oprzyrządowanie»: opracowanie narzędzi i technik zwiększających wrażliwość administracji na sygnały płynące z otoczenia. Dopiero spełnienie tych wszystkich warunków pozwala mieć nadzieję na prawdziwe «responsywne» rządzenie" ${ }^{\prime \prime} 1$.

\section{Urzędowe interpretacje prawa podatkowego}

Pozostaje zatem przystąpić do realizacji pierwszego z założonych celów niniejszego opracowania, tj. dokonać weryfikacji tezy B. Brzezińskiego, że urzędowe interpretacje prawa podatkowego obowiązujące w polskim systemie prawnym mogą być charakteryzowane jako instrument wzmagania jego responsywności. $W$ tym celu należy przeanalizować przepisy tworzące omawianą instytucję i określić zachodzące w nich zmiany.

Po pierwsze, wypada zauważyć, że w literaturze wskazuje się na dwie podstawowe funkcje, jakie mają pełnić urzędowe interpretacje

${ }^{29}$ M. Kulesza, D. Sześciło, Polityka administracyjna i zarządzanie publiczne, Warszawa 2013, s. 116.

${ }^{30}$ Ibidem, s. 112.

${ }^{31}$ J. Herbst, op. cit., s. 96. 
prawa podatkowego: informacyjną oraz gwarancyjną (ochronną) $)^{32}$. Obie funkcje wynikają z konieczności zapewnienia podatnikom poczucia pewności prawa i zaufania do organów państwa w sytuacji znacznej zmienności i wysokiego stopnia skomplikowania prawa podatkowego ${ }^{33}$.

Na funkcje interpretacji w kontekście zasad pewności prawa i zaufania do organów państwa zwrócono uwagę w uzasadnieniu do nowelizacji przepisów Ustawy z dnia 29 sierpnia $1997 \mathrm{r}$. Ordynacja podatkowa ${ }^{34}$, która weszła w życie w dniu 1 lipca 2007 r.: „zasada państwa prawnego wymaga, aby normy prawne, nakładające na obywateli obowiązki podatkowe, były na tyle jasne i zrozumiałe, by ciężar podatkowy stał się możliwy do przewidzenia. Tego wymagają zasady pewności prawa, bezpieczeństwa prawnego oraz zaufania do państwa i stanowionego w nim prawa, wyprowadzone z zasady państwa prawnego. [...] Stabilne prawo podatkowe jest jednym $z$ istotnych elementów prowadzenia działalności gospodarczej, umożliwia bowiem planowanie działań przedsiębiorcy oraz w znacznym stopniu determinuje podejmowane przez niego decyzje. Stabilność prawa podatkowego zapewnia nie tylko stanowienie jasnych i przejrzystych przepisów, ale też ich jednolite interpretowanie przez organy podatkowe. Ten drugi cel mają realizować przepisy dotyczące "wiążących interpretacji prawa podatkowego" ${ }^{35}$.

Funkcja informacyjna urzędowych interpretacji prawa podatkowego wyraża się w rozpowszechnianiu wiedzy na temat właściwego sposobu wykładni i stosowania przepisów prawa podatkowego ${ }^{36}$. Interpretacje nazywane są "instrumentem usuwania niejasności co do prawa" ${ }^{37}$.

${ }^{32}$ Z. Kmieciak, Proceduralne problemy wiążacych interpretacji prawa podatkowego, „Państwo i Prawo" 2006, nr 4, s. 21-22; H. Filipczyk, Indywidualne interpretacje prawa podatkowego - prawo i praktyka, Warszawa 2011, s. 10.

${ }^{33}$ H. Filipczyk, op. cit., s. 9-13. Urzędowe interpretacje prawa podatkowego mają szczególne znaczenie w sytuacji stosowania przez ustawodawcę techniki samoobliczania (samowymiaru) podatku, która powoduje przerzucenie na podatnika obowiązku dokonania wykładni prawa podatkowego. Podatnik w procesie stosowania prawa podatkowego musi sam ustalić swoją należność podatkową, a rola organów podatkowych ogranicza się, co do zasady, do kontroli prawidłowości działań podatnika (por. R. Mastalski, Charakter prawny interpretacji prawa podatkowego dokonywanej przez Ministra Finansów, "Jurysdykcja Podatkowa" 2007, nr 1, s. 5).

${ }^{34}$ Dz.U. Nr 137, poz. 926 ze zm., dalej „o.p." lub „Ordynacja”. Uzasadnienie do Ustawy z dnia 16 XI 2006 r. o zmianie ustawy - Ordynacja podatkowa oraz o zmianie niektórych innych ustaw (Dz.U. Nr 217, poz. 1590).

${ }^{35}$ Uzasadnienie projektu ustawy o zmianie ustawy - Ordynacja podatkowa oraz o zmianie niektórych innych ustaw, druk sejmowy nr 731/V kadencja, s. 2-3.

${ }^{36}$ H. Filipczyk, op. cit., s. 10-11.

${ }^{37}$ Z. Kmieciak, op. cit., s. 21-22. 
Interpretacje ogólne mają zapewniać jednolite stosowanie przepisów prawa podatkowego przez organy podatkowe, natomiast interpretacje indywidualne stanowić wskazówkę dla podmiotu, który wystąpił o interpretację, jak należy stosować przepisy prawa podatkowego w konkretnej sprawie. Jednocześnie oba rodzaje interpretacji, ze względu na wyrażony w art. 14i Ordynacji obowiązek ich publikacji, służą pomocą wszystkim podmiotom dokonującym wykładni przepisów prawa podatkowego ${ }^{38}$. W literaturze przedmiotu wskazuje się, że publikowanie interpretacji jest niezbędne, ponieważ tylko poprzez fakt ich ujawnienia mogą one pełnić swoje funkcje. Wyrazem funkcji informacyjnej interpretacji jest więc ich publikacja. Co ważne, publikacja interpretacji indywidualnych, po usunięciu danych identyfikujących wnioskodawców oraz inne podmioty wskazane w treści interpretacji, zbliża je w sensie funkcjonalnym do interpretacji ogólnych ${ }^{39}$.

Funkcja gwarancyjna (ochronna) urzędowych interpretacji prawa podatkowego realizowana jest poprzez ochronę podatnika ${ }^{40}$ działającego w zaufaniu do informacji zawartej $\mathrm{w}$ interpretacji ${ }^{41}$. Jest to tzw. zasada nieszkodzenia, zgodnie z którą podmiot, który zastosował się do interpretacji, nie może z tego tytułu ponosić negatywnych skutków prawnych $^{42}$. Przepisy Ordynacji nie nakładają na podatnika obowiązku zachowania się zgodnie z treścią interpretacji. Dopiero zastosowanie się przez podatnika do stanowiska w niej zawartego może rodzić określone konsekwencje. $Z$ przepisów prawa wynika bowiem gwarancja dla podatnika, że zastosowanie się do interpretacji nie będzie mu szkodziło, i to niezależnie od prawidłowości tego stanowiska. Z kolei dla organu podatkowego ze zgodnym z interpretacją zachowaniem podatnika,

${ }^{38}$ Jak wskazują W. Nykiel i D. Strzelec, „we współczesnych systemach podatkowych prawo do informacji (prawo do bycia poinformowanym) należy do podstawowych praw podatnika. W sytuacji, gdy unormowania prawa podatkowego rodzą trudności interpretacyjne, podatnik z reguły ma prawo uzyskać od organów podatkowych, na tle konkretnego stanu faktycznego, ich wykładnię. Unormowania gwarantujące realizację tego prawa eliminują niepewność podatnika odnoszącą się do jego obowiązków i uprawnień i pozwalają na właściwe projektowanie przyszłych przedsięwzięć gospodarczych" (W. Nykiel, D. Strzelec, Interpretacje przepisów prawa podatkowego wydawane w indywidualnych sprawach (1), „Przegląd Podatkowy” 2007, nr 5, s. 34).

${ }^{39}$ C. Kosikowski i in., Ordynacja podatkowa, Warszawa 2009, s. 148-150.

${ }^{40}$ Zgodnie $\mathrm{z}$ art. $14 \mathrm{p}$ Ordynacji przepisy dotyczące interpretacji stosuje się odpowiednio do należności płatników lub inkasentów, zobowiązań osób trzecich oraz do należności, o których mowa w art. $52 \S 1$ o.p.

${ }^{41}$ H. Filipczyk, op. cit., s. 11.

${ }^{42}$ C. Kosikowski i in., op. cit., s. 153. 
np. na etapie składania zeznania podatkowego uwzględniającego treść interpretacji, związany jest obowiązek powstrzymania się od działania, które mogłoby szkodzić podatnikowi ${ }^{43}$. Skutki zastosowania się podatnika do interpretacji zostały uregulowane w obowiązującym stanie prawnym w art. 14k-14n Ordynacji.

Prześledzenie rozwoju polskich regulacji prawnych dotyczących urzędowych interpretacji prawa podatkowego umożliwi uzyskanie odpowiedzi na pytanie, jak w poszczególnych okresach realizowane były opisane wyżej funkcje informacyjna i gwarancyjna (ochronna) ${ }^{44}$. I tak, do momentu wejścia w życie Ordynacji interpretacje były wydawane przez Ministra Finansów ${ }^{45}$ na podstawie art. 4 Ustawy z dnia 19 grudnia 1980 r. o zobowiązaniach podatkowych ${ }^{46}$. Zgodnie $\mathrm{z}$ tym przepisem Minister Finansów sprawował ogólny nadzór w sprawach zobowiązań podatkowych i w ramach tego nadzoru zapewniał jednolitość stosowania przepisów przez organy podatkowe. Przepis ten służył jako podstawa prawna wydawania klasycznych interpretacji prawa podatkowego, jak również prowadzenia przez Ministra Finansów działalności określanej w doktrynie jako de facto prawotwórcza ${ }^{47}$. Odnosząc ówczesną regulację prawną do funkcji informacyjnej, należy wskazać, że przepisy prawa nie przewidywały nakazu publikacji interpretacji. W praktyce były one publikowane w prywatnych wydawnictwach, $\mathrm{np}$. w czasopismach zajmujących się problematyką podatkową, bardzo często w opracowaniach redakcyjnych, a nie w pełnej wersji. Część interpretacji - przede wszystkim tych, które miały charakter właściwie precedensowy - była publikowana w Dzienniku Urzędowym Ministra Finansów. Większość interpretacji była rozsyłana do organów podatkowych ${ }^{48}$. Z kolei jeżeli

${ }^{43}$ Ordynacja podatkowa. Komentarz, pod red. B. Brzezińskiego, Toruń 2007, s. 97-98.

${ }^{44} \mathrm{~W}$. Morawski zauważa, że "regulacja oficjalnej interpretacji prawa podatkowego była w Polsce przedmiotem dość częstych zmian. Zmiany miały różnorodny charakter. W wypadku niektórych problemów mamy do czynienia ze swoistą ewolucją regulacji, a w niektórych sytuacjach można mówić o «rewolucyjnych» zmianach. W efekcie trudno wskazać jakąś niezależną od momentu (ponadczasową) specyfikę polskiej regulacji dotyczącej oficjalnych interpretacji prawa podatkowego. W ciągu ostatnich trzydziestu lat [...] można mówić o kilku odrębnych modelach regulacji oficjalnych interpretacji prawa podatkowego, które niekiedy łączą pewne wspólne elementy" (W. Morawski, op. cit., s. 222).

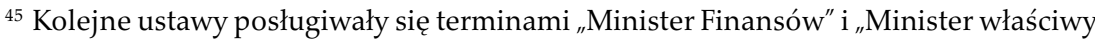
do spraw finansów publicznych". W dalszej części opracowania: „Minister Finansów”.

${ }^{46}$ Dz.U. Nr 27, poz. 111 ze zm.

${ }^{47}$ Por. W. Morawski, op. cit., s. 223.

${ }^{48}$ Ibidem, s. 224. 
chodzi o realizację funkcji gwarancyjnej (ochronnej), na gruncie ustawy o zobowiązaniach podatkowych nie funkcjonowały żadne przepisy zapewniające ochronę interesów podatników działających w zaufaniu do interpretacji wydawanych przez Ministra Finansów. Ochrona taka wynikała co najwyżej z orzecznictwa sądów administracyjnych, w którym kształtowały się dwie przeciwne linie orzecznicze dotyczące interpretacji wydawanych na podstawie art. 4 ustawy o zobowiązaniach podatkowych. Zgodnie z pierwsza, nazywaną "legalistyczną", sądy nie były skłonne stosować sprzecznych z prawem interpretacji wydawanych przez Ministra Finansów, nawet jeżeli okazywały się one korzystniejsze dla podatników niż obowiązujące przepisy. Według drugiej linii orzeczniczej, kładącej nacisk na zasadę zaufania, zastosowanie się przez podatnika do wykładni przepisów prawa podatkowego zawartej $\mathrm{w}$ interpretacji nie mogło powodować dla niego negatywnych konsekwencji ${ }^{49}$. Na ten stan niepewności sytuacji podatnika przed wejściem w życie Ordynacji podatkowej zwrócił uwagę ustawodawca w cytowanym już uzasadnieniu do nowelizacji, która weszła w życie w dniu 1 lipca 2007 r.: „jeszcze w 1997 roku interpretacje Ministra Finansów nie wymagały publikacji, podatnik nie dysponował formalnym prawem wnioskowania o interpretację w swojej indywidualnej sprawie, a nawet jeżeli takową otrzymał, nie korzystał $\mathrm{z}$ żadnej normatywnej ochrony w zakresie objętym interpretacją" ${ }^{\prime \prime 0}$.

Od 1 stycznia 1998 r., a więc od dnia wejścia w życie Ordynacji, można wyróżnić kilka okresów, w których instytucja urzędowych interpretacji

${ }^{49}$ Ibidem, s. 225-228. W. Morawski wskazuje, że "jeżeli podatnik uzyskiwał ochronę, to tylko dzięki inwencji sądu administracyjnego, którego niektóre składy skłonne były poszukiwać źródeł takiej ochrony w zasadach ogólnych prawa, wywodzonych zazwyczaj z przepisów konstytucyjnych. [...] Było to rozwiązanie, które nie zapewniało jednak efektywnej ochrony interesów podatników i to z kilku względów. Po pierwsze, nie istniała w tym zakresie jednolita linia orzecznicza sądów administracyjnych. Podatnik nie miał więc pewności, czy akurat ten skład sędziowski akceptuje koncepcję dopuszczającą zastosowanie zasady nieszkodzenia. Jednocześnie bowiem zapadały wyroki oparte na zasadzie legalizmu, w których sądy wskazywały na brak podstaw prawnych do odstąpienia od stosowania przepisów prawa, nawet gdy miałoby to być związane z naruszeniem pewnych oczekiwań, które podatnik wiązał ze znanym mu stanowiskiem interpretacyjnym organu podatkowego. W wyrokach zaliczanych do nurtu legalistycznego wskazywano co najwyżej na możliwość ubiegania się o zastosowanie ulgi w zapłacie podatku. Po drugie, nawet gdy sąd akceptował zasadę nieszkodzenia, to unikał zazwyczaj sformułowania wyraźnego stanowiska, jak należy ją rozumieć, czy oznacza to związanie organu interpretacja, czy możliwość zastosowania ulgi w zapłacie podatku, zwolnienie z obowiązku zapłaty podatku, czy tylko odsetek etc." (ibidem, s. 338).

${ }^{50}$ Uzasadnienie projektu ustawy o zmianie ustawy - Ordynacja podatkowa oraz o zmianie niektórych innych ustaw, druk sejmowy nr 731/V kadencja, s. 3. 
prawa podatkowego przechodziła liczne zmiany. Do 31 grudnia $2002 \mathrm{r}$. regulację prawną interpretacji zawierał ówczesny art. 14 Ordynacji. W stosunku do ustawy o zobowiązaniach podatkowych nowością było rozróżnienie interpretacji ogólnych i indywidualnych. Podział ten, mimo licznych zmian samej instytucji interpretacji, obowiązuje do dnia dzisiejszego. Zgodnie z obowiązującymi wówczas przepisami interpretacje ogólne były wydawane przez Ministra Finansów, a interpretacje indywidualne przez właściwe organy podatkowe pierwszej instancji. Art. 14 \& 3 Ordynacji przewidywał konieczność publikacji interpretacji ogólnych w Biuletynie Skarbowym Ministerstwa Finansów ${ }^{51}$, zaś art. 14 § 6 Ordynacji wskazywał, że zastosowanie się przez podatnika do interpretacji ogólnej nie może mu szkodzić. Przepisy te nie odnosiły się jednak do interpretacji indywidualnych. Nie istniał obowiązek ich publikacji, a zasadę nieszkodzenia w stosunku do interpretacji indywidualnych sądy administracyjne, podobnie jak za czasów obowiązywania ustawy o zobowiązaniach podatkowych, wyprowadzały z zasad konstytucyjnych ${ }^{52}$. Warto również zauważyć, że Ordynacja nie wskazywała, jak należy rozumieć zasadę nieszkodzenia odnoszącą się do interpretacji ogólnych. Co więcej, zasada ta znajdowała zastosowanie jedynie do podatników, a nie obejmowała płatników i inkasentów. Zakres jej zastosowania był więc znacznie ograniczony ${ }^{53}$.

Zasadnicza modyfikacja przepisów regulujących wydawanie indywidualnych interpretacji podatkowych weszła w życie w dniu 1 stycznia 2003 r. ${ }^{54} \mathrm{~W}$ nowym modelu wprowadzono istotne zmiany $\mathrm{w}$ zakresie spełniania przez interpretacje funkcji informacyjnej i gwarancyjnej (ochronnej) ${ }^{55}$. Po pierwsze, Ordynacja podatkowa przewidywała $\mathrm{w}$ art. 14 § 2 obowiązek publikacji interpretacji ogólnych w urzędowym czasopiśmie Ministra Finansów - Dzienniku Urzędowym Ministra

${ }^{51}$ W. Morawski zauważa, że Biuletyn Skarbowy Ministerstwa Finansów był czasopismem prywatnym (W. Morawski, op. cit., s. 236).

${ }^{52}$ H. Filipczyk, op. cit., s. 16.

${ }^{53}$ W. Morawski, op. cit., s. 241-243.

${ }^{54}$ Ustawa z dnia 12 IX 2002 r. o zmianie ustawy - Ordynacja podatkowa oraz o zmianie niektórych innych ustaw (Dz.U. Nr 169, poz. 1387).

${ }^{55}$ Nowelizacja wprowadzała również kontrowersyjne sformułowanie w art. $14 \S 2$ o.p., zgodnie z którym interpretacje ogólne wiążą organy podatkowe i organy kontroli skarbowej. Art. 14 \& 2 o.p. został uznany przez Trybunał Konstytucyjny w wyroku z $11 \mathrm{~V}$ 2004 r. (sygn. 4/03) za niezgodny z art. 78 oraz art. 93 ust. 2 zd. 2 Konstytucji RP w części stanowiącej, że interpretacje ministra właściwego do spraw finansów publicznych wiążą organy podatkowe i organy kontroli skarbowej. 
Finansów, zaś w art. 14a § 5 Ordynacji obowiązek zamieszczania interpretacji indywidualnych na stronach internetowych właściwych izb skarbowych bez podania danych identyfikujących podatników. Po drugie, $w$ art. $14 \S 3$ Ordynacji ustawodawca sprecyzował rozumienie zasady nieszkodzenia i odniósł ją już nie tylko do podatników, ale również do płatników i inkasentów. W zakresie wynikającym z zastosowania się do interpretacji wobec podatnika, płatnika lub inkasenta nie wszczynano postępowania karnoskarbowego, nie naliczano odsetek za zwłokę oraz nie ustalano dodatkowego zobowiązania w rozumieniu przepisów o podatku od towarów i usług. Przepis przewidywał również, że zastosowanie się do interpretacji nie zwalnia z obowiązku zapłaty podatku, ale może stanowić przesłankę do umorzenia zaległości podatkowych, jeżeli zaległości te powstały na skutek zastosowania się do interpretacji. W uzasadnieniu do ustawy wskazano, że "celem zasady «nieszkodzenia» jest doprowadzenie do takiej sytuacji, w której na podatniku ciąży tylko ten obowiązek podatkowy, który by istniał przy prawidłowej interpretacji przepisów i jej zastosowaniu przez podatnika. Konstytucyjny obowiązek zapłaty podatku nie może być traktowany jako szkoda. «Nieszkodzenie» nie może więc oznaczać zwolnienia z obowiązku zapłaty podatku, na podstawie art. 14, co nie pozbawia prawa do ubiegania się o umorzenie zaległości podatkowej. Umorzenie zaległości opiera się jednak na innych przesłankach" ${ }^{\prime \prime 6}$. Należy również zwrócić uwagę, że zgodnie $z$ art. 14a $\S 4$ Ordynacji po raz pierwszy zasada nieszkodzenia została również odniesiona do interpretacji indywidualnych.

Kolejna znacząca zmiana modelu urzędowych interpretacji prawa podatkowego weszła w życie 1 stycznia $2005 \mathrm{r}^{57} \mathrm{~W}$ analizowanym zakresie podkreślić należy dalszy rozwój funkcji gwarancyjnej (ochronnej) interpretacji. Przede wszystkim zasadą nieszkodzenia objęto również zakaz określania lub ustalania zobowiązania podatkowego w wysokości sprzecznej z interpretacją. Co więcej, interpretacje indywidualne stały się wiążące dla organów podatkowych. Model urzędowych interpretacji prawa podatkowego obowiązujący od 1 stycznia 2005 r. słusznie budził jednak liczne kontrowersje $\mathrm{w}$ literaturze przedmiotu ${ }^{58}$. Doprowadziło to do konieczności następnej zmiany Ordynacji.

${ }^{56}$ Uzasadnienie projektu ustawy o zmianie ustawy - Ordynacja podatkowa oraz o zmianie niektórych innych ustaw, druk sejmowy nr 414/IV kadencja, s. 3.

${ }^{57}$ Ustawa z dnia 2 VII 2004 r. Przepisy wprowadzające ustawę o swobodzie działalności gospodarczej (Dz.U. Nr 173, poz. 1808).

${ }^{58}$ Listę krytycznych publikacji przytacza W. Morawski (op. cit., s. 257, przypis 601). Na przykład W. Nykiel wskazuje, że „zasadnicze zastrzeżenia budzi forma prawna, w jakiej 
Kolejna nowelizacja instytucji urzędowych interpretacji prawa podatkowego weszła w życie 1 lipca $2007 \mathrm{r} .{ }^{59}$ Inaczej niż to było przed tą data, kompetencję do wydawania interpretacji indywidualnych powierzono nie organom podatkowym pierwszej instancji, ale tak jak w przypadku interpretacji ogólnych Ministrowi Finansów ${ }^{60}$. Uzasadnienie do projektu ustawy wskazuje, że „zmniejszenie ilości organów uprawnionych do wydawania interpretacji przyczyni się do ujednolicenia stosowania prawa przez aparat skarbowy i ułatwi Ministrowi Finansów sprawowanie ogólnego nadzoru w tym zakresie"61. Na etapie prac legislacyjnych wskazywano, że jest to rozwiązanie bardziej prawidłowe systemowo niż przyznanie kompetencji w tym zakresie organom podatkowym pierwszej instancji ${ }^{62}$. Analizując funkcję informacyjną interpretacji, można

udzielane mają być interpretacje w indywidualnych sprawach. Interpretacje te udzielane mają być bowiem w formie postanowienia, na które służy zażalenie. Postanowienie to może być zmienione lub uchylone przez organ odwoławczy w drodze decyzji. Jak wiadomo, zarówno postanowienie, jak i decyzja są indywidualnymi aktami administracyjnymi i stanowią rozstrzygnięcie sprawy (co do zasady: postanowienie - procesowej, decyzja - materialnoprawnej). Są więc władczym jednostronnym rozstrzygnięciem o prawach lub obowiązkach jednostkowo określonego podmiotu w konkretnej sprawie. Tymczasem istota interpretacji sprowadza się, ogólnie rzecz biorąc, do formuły: przepis $\mathrm{P}$ (norma N) ma znaczenie $\mathrm{Z}$. Tak więc natura prawna postanowienia i decyzji sprawia, że nie powinny one być formą prawną dla interpretacji. Błąd ustawodawcy w tym zakresie ma swoje następstwa. Nie wiadomo bowiem, na czym ma polegać wykonywanie decyzji zawierającej interpretację czy wstrzymanie jej wykonania, o czym mówią przepisy. Niezależnie od tych uwag rodzi się także pytanie, dlaczego postanowienie ma być zmieniane decyzją" (W. Nykiel, Wiążace interpretacje prawa podatkowego w indywidualnych sprawach podatników, płatników i inkasentów - niektóre możliwe rozwiązania, w: W kregu prawa podatkowego i finansów publicznych - księga dedykowana profesorowi Cezaremu Kosikowskiemu w 40-lecie pracy naukowej, pod red. H. Dzwonkowskiego i in., Lublin 2005, s. 281-282).

${ }^{59}$ Ustawa z dnia 16 XI 2006 r. o zmianie ustawy - Ordynacja podatkowa oraz o zmianie niektórych innych ustaw (Dz.U. Nr 217, poz. 1590).

${ }^{60}$ Zgodnie z art. 14b § 6 minister właściwy do spraw finansów publicznych w celu zapewnienia jednolitości wydawanych wiążących interpretacji i usprawnienia obsługi wnioskodawców może, w drodze rozporządzenia, upoważnić podległe organy do wydawania interpretacji indywidualnych $w$ jego imieniu i w ustalonym zakresie, określając jednocześnie właściwość rzeczową i miejscową upoważnionych organów. Na podstawie tego przepisu Minister Finansów wydał w dniu 22 IV 2015 r. rozporządzenie w sprawie upoważnienia do wydawania interpretacji przepisów prawa podatkowego (Dz.U. poz. 643), w którym upoważnił dyrektorów Izb Skarbowych w: Bydgoszczy, Katowicach, Łodzi, Poznaniu i Warszawie do wydawania interpretacji indywidualnych w imieniu Ministra Finansów.

${ }^{61}$ Uzasadnienie projektu ustawy o zmianie ustawy - Ordynacja podatkowa oraz o zmianie niektórych innych ustaw, druk sejmowy nr 731/V kadencja, s. 4.

${ }^{62}$ B. Brzeziński, Opinia o rządowym projekcie ustawy o zmianie ustawy Ordynacja podatkowa oraz o zmianie niektórych innych ustaw (druk sejmowy 731), s. 4. 
wskazać, że zgodnie z art. 14i § 1 Ordynacji interpretacje ogólne mają być publikowane już nie tylko w Dzienniku Urzędowym Ministra Finansów, ale również w Biuletynie Informacji Publicznej. Podobnie interpretacje indywidualne, zgodnie $z$ art. $14 \mathrm{i} \& 3$ Ordynacji, są publikowane w Biuletynie. Biuletyn Informacji Publicznej funkcjonuje na podstawie art. 8 Ustawy z dnia 6 września 2001 r. o dostępie do informacji publicznej ${ }^{63} \mathrm{i}$ jest urzędowym publikatorem teleinformatycznym powołanym $\mathrm{w}$ celu powszechnego udostępniania informacji publicznej w postaci ujednoliconego systemu stron w sieci teleinformatycznej. Zarówno w przypadku interpretacji ogólnych, jak i indywidualnych ustawodawca wprowadził konieczność ich publikacji bez zbędnej zwłoki ${ }^{64}$.

Wprowadzone $z$ dniem 1 lipca 2007 r. zmiany w zakresie publikacji interpretacji są kolejnym krokiem w stronę pełnego urzeczywistnienia funkcji informacyjnej tej instytucji. Z kolei w przypadku funkcji gwarancyjnej (ochronnej) konstrukcja ochrony opiera się w obowiązującym stanie prawnym nie na związaniu organu podatkowego interpretacja, jak to miało miejsce przed nowelizacja, ale na instytucji zwolnienia ${ }^{65}$. Chodzi tutaj o zwolnienie z zapłaty podatku (art. $14 \mathrm{~m}$ Ordynacji), zwolnienie z odsetek za zwłokę (art. 14k § 3 Ordynacji) oraz zwolnienie z konsekwencji karnoskarbowych (art. 14k § 3 Ordynacji) ${ }^{66}$.

Doniosłe zmiany $\mathrm{w}$ instytucji interpretacji ogólnych prawa podatkowego zostały wprowadzone $\mathrm{z}$ dniem 1 stycznia $2012 \mathrm{r} .{ }^{67}$ Zgodnie z nowym brzmieniem art. 14a § 1 Ordynacji ogólne interpretacje prawa podatkowego mogą być wydawane już nie tylko z urzędu, ale również

${ }^{63}$ Dz.U. Nr 112, poz. 1198.

${ }^{64} \mathrm{~W}$ przypadku interpretacji ogólnych ustawa posługuje się zwrotem „bez zbędnej zwłoki", zaś odnośnie do interpretacji indywidualnych "niezwłocznie".

${ }^{65}$ W. Morawski, op. cit., s. 341.

${ }^{66}$ Ordynacja podatkowa, pod red. H. Dzwonkowskiego, Warszawa 2011, s. 203. Warto zaznaczyć, że zakres ochrony podatnika wynikający z zastosowania się do interpretacji w przypadku, gdy okazała się ona nieprawidłowa, uzależniony jest od tego, czy skutki podatkowe związane ze zdarzeniem, któremu odpowiada stan faktyczny będący przedmiotem interpretacji, miały miejsce przed jej opublikowaniem czy po nim. Jeżeli skutki podatkowe wystąpiły przed dniem opublikowania interpretacji, zastosowanie się do interpretacji, zgodnie $\mathrm{z}$ art. $14 \mathrm{k}$ i art. $14 \mathrm{l}$ o.p., chroni wyłącznie przed naliczeniem odsetek za zwłokę oraz odpowiedzialnością karnoskarbowa, nie zwalnia jednak z obowiązku zapłaty podatku. Natomiast jeżeli skutki podatkowe wystąpiły po opublikowaniu interpretacji, to zgodnie $\mathrm{z}$ art. $14 \mathrm{~m}$ o.p. zastosowanie się do tej interpretacji zwalnia z obowiązku zapłaty podatku (ibidem, s. 159).

${ }^{67}$ Ustawa z dnia 16 IX 2011 r. o redukcji niektórych obowiązków obywateli i przedsiębiorców (Dz.U. Nr 232, poz. 1378). 
na wniosek, przy czym wnioskodawcą nie może być organ administracji publicznej. Z kolei w dniu 1 stycznia 2016 r. $^{68}$ do Ordynacji został dodany art. 14a $\S 1$ a, który wskazuje obligatoryjne elementy interpretacji ogólnej. Jeżeli zaś chodzi o interpretacje indywidualne od 1 lipca 2016 r. ${ }^{69}$ będą one wydawane już nie przez Ministra Finansów, ale dyrektora Biura Krajowej Informacji Podatkowej ${ }^{70}$. Z tym dniem uchylony zostanie również przepis art. 14b § 6 Ordynacji, który dawał Ministrowi Finansów kompetencję do upoważnienia podległych organów do wydawania interpretacji indywidualnych w jego imieniu. Wskazane nowelizacje nie wprowadzaja jednak zasadniczych zmian w zakresie funkcji informacyjnej (art. 14i Ordynacji) i gwarancyjnej (ochronnej) (art. 14k-14n Ordynacji) urzędowych interpretacji prawa podatkowego będących przedmiotem niniejszego opracowania.

\section{Podsumowanie}

Podsumowując powyższe rozważania, wypada odnieść się do zasygnalizowanych na wstępie wątpliwości, w szczególności w zakresie pytania o responsywność mechanizmu udzielania urzędowych interpretacji prawa podatkowego. Jak wynika $\mathrm{z}$ analizy zarówno przepisów regulujących wydawanie interpretacji, jak i argumentów formułowanych na ich uzasadnienie, a wreszcie $\mathrm{z}$ formułowanej $\mathrm{w}$ literaturze oceny funkcji obowiązywania tych przepisów, z całą pewnością można mówić o interpretacjach podatkowych jako elemencie instrumentarium modelu autonomicznego. Służą one przede wszystkim realizacji postulatu pewności prawa i budowania zaufania podatników do administracji podatkowej. Wobec tego stwierdzenia oraz w kontekście przywołanej tezy B. Brzezińskiego pojawia się zasadnicza wątpliwość: Czy istnieją argumenty, które pozwalałyby przyjąć, że regulacja wydawania interpretacji podatkowych wybija się ponad swój autonomiczny charakter, w kierunku responsywności?

W świetle przeprowadzonych rozważań na temat pojęcia responsywności można uznać, że kategoryczne twierdzenie, iż analizowana

${ }^{68}$ Ustawa z dnia 10 IX 2015 r. o zmianie ustawy - Ordynacja podatkowa oraz niektórych innych ustaw (Dz.U. poz. 1649).

${ }^{69}$ Ustawa z dnia 10 VII 2015 r. o administracji podatkowej (Dz.U. poz. 1269).

${ }^{70}$ Por. T. Janicki, W. Morawski, Zmiany w zakresie urzędowych interpretacji prawa podatkowego, „Przegląd Podatkowy” 2015, nr 11, s. 23-24. 
regulacja jest oczywistym przykładem modelu responsywnego, jest kontrowersyjne. Jak wynika z przedstawionej charakterystyki, responsywność zarezerwowana jest raczej dla określenia sytuacji, w której urzeczywistnia się negocjacyjny model podejmowania decyzji. Jako przykład wskazuje się najczęściej regulacje zbiorowych układów pracy, które $\mathrm{w}$ ramach prawa pracy faktycznie urzeczywistniaja postulat responsywności prawa ${ }^{71}$. Analiza regulacji urzędowych interpretacji prawa podatkowego prowadzi do wniosku, że ze względu na przypisywane instytucji ratio legis należy scharakteryzować ją jako odpowiadająca przede wszystkim modelowi autonomicznemu.

Zarazem jednak - co podkreślono już wcześniej - model prawa responsywnego nie podważa atrybutów modelu autonomicznego. Przeciwnie, to z nich wyrasta, a funkcjonowanie jego narzędzi uwarunkowane jest sprawnym funkcjonowaniem narzędzi o charakterze gwarancyjnym. Nie sposób też pomijać, że współistnienie z rozwiązaniami charakterystycznymi dla modelu autonomicznego jest warunkiem koniecznym dla zabezpieczenia prawidłowego funkcjonowania elementów mających wzmagać responsywność prawa. Należy bowiem przyjąć, za J. Herbstem, iż „jeśli o responsywności myślimy w kategoriach efektywnych mechanizmów nacisku obywateli na programy i działania polityczne, to trzeba odnotować, że istnieje pewna granica elastyczności tych programów, poza którą responsywne rządy zmieniają się bądź w «korporację» (kiedy nacisk ten wywierają grupy interesów, bądź w «demokrację sondażową» (kiedy głównym kryterium polityki staje się walka o elektorat)"72.

O ile więc nawet przyjmujemy, że regulacja udzielania interpretacji odpowiada modelowi autonomicznemu, to jednak nie sposób nie dostrzegać, że ma również cechy zbliżające ją do modelu responsywnego. Niezależnie bowiem od faktu, że nie występuje w niej element negocjacyjny, opiera się jednak na interakcji pomiędzy podatnikiem a organem administracji podatkowej. W ramach tej interakcji organ odpowiada na zgłoszoną potrzebę społeczną w zakresie niejasności prawa, co de iure - choćby ze względu na możliwość wniesienia skargi na treść interpretacji - odbywa się w ramach wolnej od zewnętrznego przymusu sytuacji komunikacyjnej.

O ile więc nie jest oczywiste prima facie, że mechanizm udzielania urzędowych interpretacji prawa podatkowego odpowiada modelowi

${ }^{71}$ Por. M. Zirk-Sadowski, op. cit., s. 19.

72 J. Herbst, op. cit., s. 94. 
prawa responsywnego, to rację ma B. Brzeziński, stwierdzając, iż jest "wyrazem realizacji tego modelu". Uzasadniają to ujawnione determinanty ewolucji przepisów, tj. umacnianie gwarancyjnej funkcji mechanizmu wydawania interpretacji i stopniowe uelastycznianie procedury reagowania na potrzeby społeczne i ustalania treści obowiązującego prawa. Ewolucja omawianej instytucji dobrze obrazuje przy tym drogę, jaką polskie prawo podatkowe przeszło w ostatnim ćwierćwieczu - od ustroju o niewątpliwie represyjnym charakterze, w którym prawo podatkowe stanowiło głównie narzędzie eliminacji jednostek gospodarki nieuspołecznionej ${ }^{73}, \mathrm{w}$ stronę ustroju charakteryzującego się autonomią prawa względem woli politycznej organów władzy państwowej, gdzie praktyka systemu podatkowego podporządkowana jest naczelnej dyrektywie państwa prawnego - budowaniu zaufania do państwa i prawa. Na tym gruncie pojawiają się również coraz częściej instytucje umożliwiające realizację postulatu responsywności systemu prawnego, co zostało już odnotowane i zasadniczo zaaprobowane w nauce prawa podatkowego $^{74}$.

Wypada jeszcze przywołać postawione na wstępie pytanie o ocenę projektowanych zmian prawa podatkowego $\mathrm{w}$ zakresie mechanizmu wydawania interpretacji podatkowych. Należy przy tym raz jeszcze podkreślić, że celem opracowania nie była ocena zasadności wprowadzania do prawa podatkowego klauzuli przeciwko unikaniu opodatkowania czy pojęcia nadużycia prawa. Chodziło jedynie o spojrzenie na związaną z ich wprowadzeniem propozycję ograniczenia możliwości uzyskania interpretacji w perspektywie uwzględniającej szerszy kontekst tradycji polskiego prawa podatkowego. Takie podejście umożliwia bowiem dostrzeżenie tych skutków wprowadzenia projektowanych rozwiązań, które umykają rozważaniom ograniczonym do doraźnej analizy o czysto technicznym charakterze, a które mogłyby - i jak się zdaje, powinny - być wzięte pod uwagę w procesie tworzenia prawa. Poza kontynuowaniem dyskusji zainicjowanej przez B. Brzezińskiego, jej zaktualizowaniem, a w pewnym zakresie również rozwinięciem,

${ }^{73}$ Tak np. K. Sawicka, Rozwój instytucji ogólnego prawa podatkowego, w: Nauka finansów publicznych i prawa finansowego..., s. $431 \mathrm{i} \mathrm{n}$.

${ }^{74}$ Zob. np.: A. Nita, Konsensualne kształtowanie powinności podatkowej w wyniku wyboru opcji podatkowej, „Kwartalnik Prawa Podatkowego" 2012, nr 1, s. 9-27; idem, Wariantowe ksztattowanie stosunku prawnopodatkowego, w: Nauka prawa finansowego po I dekadzie XXI wieku. Księga pamiatkowa dedykowana Profesorowi Apoloniuszowi Kosteckiemu, pod red. I. Czai-Hliniak, Kraków 2012, s. 313-324. 
celem artykułu było zatem również skłonienie czytelnika do podjęcia podobnej refleksji nad proponowanymi zmianami.

W opinii autorów prowadzi ona do następującego wniosku: wyłączenie możliwości uzyskania interpretacji w zakresie tych elementów stanu faktycznego, co do których organ administracji podatkowej uzna, $\dot{z ̇ e ~ " i s t n i e j e ~ u z a s a d n i o n e ~ p r z y p u s z c z e n i e ”, ~ i z ̇ ~ p o t e n c j a l n i e ~ " m o g a ̨ ~ b y c ́ ~}$ przedmiotem decyzji wydanej z zastosowaniem art. 119a [tj. projektowanej klauzuli przeciwko unikaniu opodatkowania - dop. J.K. i P.P.] lub stanowić nadużycie prawa, o którym mowa w art. 5 Ustawy z dnia 11 marca 2004 r. o podatku od towarów i usług (Dz.U. z 2011 Nr 177, poz. 1054, z późn. zm.)", znacząco ograniczy nie tylko potencjał regulacji w zakresie wzmagania responsywności, ale nawet podważy jej cechy jako instytucji modelu autonomicznego. Istnieje bowiem niemożliwe do wykluczenia ryzyko, że ze względu na bardzo nieprecyzyjnie wyznaczony zakres sytuacji, w których możliwe będzie odmówienie ustosunkowania się do elementów stanu faktycznego mającego stanowić przedmiot interpretacji, regulacja znacząco straci swoje znaczenie w budowaniu poczucia pewności prawa. W skrajnych sytuacjach może się nawet okazać, iż w praktyce uzyskanie interpretacji będzie całkowicie niemożliwe, a wyegzekwowanie jakiegokolwiek stanowiska od organu administracji podatkowej bardzo utrudnione. Oczywiście nie jest tak, że w przypadku wprowadzenia projektowanych zmian podatnicy będą pozbawieni jakichkolwiek środków prawnych ochrony swoich interesów w związku $z$ domaganiem się wydania interpretacji. Po pierwsze, na podstawie art. 165a o.p. w zw. z art. 14h o.p. przysługiwać im będzie zażalenie na postanowienie o odmowie wydania interpretacji. Po drugie zaś, w przypadku wydania decyzji niesatysfakcjonującej podatnika (np. ze względu na brak odniesienia do wszystkich podnoszonych okoliczności stanu faktycznego), możliwe jest skorzystanie ze środków przewidzianych $\mathrm{w}$ ramach postępowania sądowoadministracyjnego ${ }^{75}, \mathrm{w}$ szczególności na podstawie art. 57a Ustawy z dnia 30 sierpnia 2002 r. Prawo o postępowaniu przed sądami administracyjnymi. Niezależnie jednak od tego, dostrzegając wynikającą ze specyfiki potencjalnego sporu praktyczną trudność ${ }^{76}$ dochodzenia praw przez podatników, uzasadnione wydaje

${ }^{75}$ A. Hanusz, Urzędowe interpretacje przepisów prawa podatkowego w Polsce oraz ich sadowoadministracyjna kontrola, "Zeszyty Naukowe Sądownictwa Administracyjnego" 2015, nr 6, s. 9 i n.

${ }^{76}$ Praktyka zdaje się potwierdzać niemożliwy do wykluczenia a priori wniosek, że już sama perspektywa zaangażowania się w zapewne długotrwały i skomplikowany spór co 
się stwierdzenie, że proponowane regulacje mogą - choć, oczywiście, nie muszą - prowadzić do zmiany istoty instytucji urzędowych interpretacji prawa podatkowego polegającej na wyrugowaniu elementów o charakterze responsywnym, osłabieniu tych o charakterze autonomicznym, a w skrajnym przypadku nawet na wprowadzeniu atrybutów charakteryzowanych w koncepcji P. Selznicka i P. Noneta jako właściwe dla modelu represyjnego.

Oczywiście, jest to konstatacja uwzględniająca rozwiązania skrajne. Autorzy nie twierdzą też, że wnioski z rozważań opartych na przedstawionym modelu teoretycznym miałyby być wiążące. Wydaje się jednak, iż nie jest właściwe całkowite ich bagatelizowanie. Co prawda, można by zapewne wskazać argumenty uzasadniające ingerencję w istotę instytucji urzędowych interpretacji prawa podatkowego, to jednak należy mieć świadomość wpływu, jaki to naruszenie może wywierać na funkcjonowanie owej instytucji, na funkcjonowanie całego systemu podatkowego, a w szerszej perspektywie - na kształtowanie ładu społecznego.

\section{A FEW REMARKS ON THE RESPONSIVENESS OF TAX LAW ON THE EXAMPLE OF OFFICIAL INTERPRETATIONS OF TAX LAW}

\section{S u m mary}

The article is an attempt to look at the development of Polish tax law through the prism of the concept of law development proposed by Ph. Selznick and Ph. Nonet. In the study Law and Society in Transition. Towards Responsive Law they distinguished three stages of evolution of legal systems: repressive, autonomous and responsive. The focus of the article is on the institution of the official interpretation of tax law, because an analysis of the transformation of the legal system allows to capture trends that are present in the development of its individual institutions as well as social relationships among its recipients. By indicating the evolution of official interpretations of tax law in its two basic functions - those of informing and those of guaranteeing (protective) - the authors point to a wider context of the development of tax law to show whether and how changes in the normative regulation of official interpretations of tax law may affect the shape of the relationship between a taxpayer and tax administration, where the perspective of the analysis of demand is the responsiveness of law. An analysis of the regulation of an official interpretation of tax law leads to the conclusion that due to the assigned ratio legis this interpretation must characterise them as corresponding mainly to the autonomous model. At the

do interpretacji wyjątkowo nieostrych elementów uchwalonych przepisów dodatkowo obniżać będzie poziom zaufania podatników do organów administracji, a wielu zapewne zniechęci do dochodzenia swych praw. 
same time a responsive model of law does not undermine the autonomous model attributes. Thus if we were to accept that the provision of interpretation corresponds to the autonomous model, it would not be possible to note that it also has attributes that make it a responsive model. Irrespective of the fact that there is no element of negotiation, it is based on the interaction between the taxpayer and the tax administration. As part of this interaction, tax administration responds to the reported social need in terms of the ambiguity of law, which de iure - not least because of the possibility of bringing an action against the content of interpretation - takes place in the framework of a communication situation that is free from external coercion.

Keywords: tax interpretation - official interpretation of the tax law - responsive law 